\title{
Assess the Determinants of Household Food Security in the Case of Agro-Pastoral Kebeles of Yabello Woreda, Southern Ethiopia
}

\author{
Ashebir Nega (Msc) Zebenay Shitaye (Msc) Teshome sirany (Msc) \\ College of Agriculture and Natural resource, department of rural development and agricultural extension, Debre \\ Markos University, p. o box 269, Debre Markos, Ethiopia
}

\begin{abstract}
This study was commenced to examine the determinants of household food security in the agro- pastoral kebeles of Yabello woreda. The analysis was based on household survey data gathered from 168 randomly selected household heads in three agro-pastoral kebeles following probability proportional to population size sampling approach (PPS).Descriptive statistics, independent sample t- test, chi-squire tests and binary logistic regression model were used to analyze the data. The results of the analysis show that from the total surveyed households $39.9 \%$ were found to be food secured while the remaining $60.1 \%$ were food insecure. Five variables which include livestock ownership, household size, size of cultivated land, use of chemical fertilizer and distance to the market were found to be significant factors affecting household status of food security in the logistic regression model output. The findings suggest the need to improve the provision of services that improve livestock and agricultural production and microfinance to encourage the adoption of agricultural technologies. More training is important to encourage diversified crop production by the households. It is also important to improve the provision of basic infrastructural services such as rural roads and markets (especially livestock market centers) to facilitate livelihood diversification.
\end{abstract}

Keywords: Household Food security, Logistic regression, Agro-pastoral, Yabello

DOI: $10.7176 / \mathrm{JPID} / 55-01$

Publication date:August $31^{\text {st }} 2020$

\section{INTRODUCTION}

\subsection{Background of the Study}

Food security and insecurity are terms used to describe whether or not households have access to sufficient quality and quantity of food. Food security issues gained prominence in the 1970s and have since been given considerable attention. Food security is perceived at the global, national, household and individual levels. Food security at global level does not guarantee food security at the national level. Moreover, food security at the national level does not guarantee food security at the household or even the individual level Osei Mensah etal (2013). Ethiopia with an estimated population of over 90 million is the second populous nation in Africa. Out of the total population $85 \%$ live in rural areas (ECSA, 2011). The country is predominantly agrarian and agriculture plays an important role in the national economy (Di Falco et al., 2011).It accounts for about $46 \%$ of the total GDP, employing and supporting about $84 \%$ of the total population as well accounting for about $90 \%$ of the export (ECSA, 2011). But its productivity in terms of feeding the country's population which is growing at $2.6 \%$ per year is dismal (Habtom et al., 2008).

Pastoral and agro pastoral communities that are living in moisture deficit areas of Ethiopia are highly exposed to food security problems. Even in the years of adequate rainfall and good harvest millions of people particularly in the lowland areas need food assistance. Recurrent droughts has become frequent and the most exacerbating factor of food insecurity and malnutrition (Dominguez, 2010).

Food insecurity in pastoral and agro-pastoral areas can be viewed in terms of chronic and transitory. Those vulnerable to chronic food insecurity are households that are either subjected to frequent or sever and regular food insecurity or households having low resilience or both. In contrast households that suffer transitory food insecurity do so over a short but intense period such as the life threatening periods of drought (CAADP, 2009).

Food security problems, causes and their consequence are widely different throughout the country. Borena Zone where Yabello Woreda is located is often affected by recurrent drought and food security problems where pastoralists and agro-pastoralists face cycles of droughts. According to Fassil (2001), drought has been recurring in Borena area since the 1970s. The major drought events in this area occurred in the years1973-1975, 1982-1985, 1993-1994 and 1999-2000 with various ecological, economic and social consequences. In particular, the 19841985 draught has contributed to depressing animal population growth by driving calf mortality rate as high as $90 \%$. In the drought that occurred during 1980 and 2000, Borena pastoral communities lost two third of their animals (IIRR, 2004). Other threat to pastoral production systems includes weak political support, land degradation, growing vulnerability to ecological and economic stress and low utilization of technologies (Fassil, 2001).

In general pastoral and agro pastoral households in the study area are currently vulnerable to food security problems even with the slightest shocks, due to degradation of traditional pastoral territory, climate change, shortage of rain fall, recurrent drought, low level of technology and limited technical support. In line with these 
facts this study was assess determinates of household food security in the agro-pastoral households of Yabello woreda.

\subsection{Statement of the Problem}

The pastoral and Agro-pastoral systems in Ethiopia have been experiencing vulnerability to environmental degradation and food security problems (Beruk, 2003). Food insecurity has characterized these areas where the majority of people depend on food assistance. The pastoral and agro-pastoral people of Yabello woreda of Borena Zone have been facing food security problem for a long time due to several factors. Livestock production is used to be the main source of income and livelihoods in the woreda. In the past, the food consumption requirement of the household is mainly obtained directly from livestock and their products and the exchange of these products with cereals in the market (Getachew, 1995). However, shift in income sources and livelihoods have occurred over time in which the food needs of the majority of households is being purchased from the market supplemented by own production. Since the income obtained from the sale of livestock and its products are not adequate to purchase enough food the people is in a rapid process of transforming its livelihood in to agro- pastoral systems (YWFSO, 2016). On the other hand, crop production is often met with crop failure or low yield. As a result the number of needy people has increased from time to time. Available data sources indicated that in the year 2015 at zonal level 145,464 people were needy. In the year 2016 the number of needy people increased up to 187,055 and attempts were made to reach them with 187,055 quintals of food by the government (BZDPPO, 2016). This shows that food security problems are increasing from time to time. Therefore, this study was designed to fill the gap that food security related researches were totally pastoral centered in the area so that it is important to touch the agro-pastoral people by assessing the main factors affecting the food security situation of agro-pastoralists in the study area.

\subsection{Objectives of the Study}

The general objective of this study was to assess the determinants of household food security in the case of agropastoral kebeles of Yabello woreda.

Specific objectives

$>$ To examine economic related characteristics of the sample households in the study area.

$>$ To analyze the institutional factors of agro pastoral households in the study area.

$>$ To assess the factors that affect household food security in the study area

\subsection{Research Questions}

\#What are the socioeconomics characteristics of the respondents in the study area?

$\$$ What is the food security status of the agro pastoral households in the study area?

\subsection{Significance of the Study}

A study about household food security status is important in this area because it provides information on the effective measures to be taken to implement appropriate strategies and enhance food security status of the study area population. Besides, the output obtained from this research will contributes to development practitioners and policy makers to acquire better knowledge to carry out development interventions to enhance food security. This study will also be important to all concerned governmental and nongovernmental organizations that are going to implement projects which are related to food security. The result of this study can also be made ready and documented at woreda level to serve as a source document for further research and other purposes necessary.

\subsection{Scope of the Study}

This study has focused on household level food security situations and coping mechanisms used by the households during food shortages in agro-pastoral kebeles of Yabello woreda. The study mainly relied on the perception of the household heads to assess their state of food security. The research was also restricted to identifying the major coping mechanisms used in the study area during food shortages as well as only the main factors affecting state of food security situations at the household level were analyzed. The study was also limited to the three purposely selected agro-pastoral kebeles of Yabello woreda by taking 168 household heads as the main target population. Finally cross-sectional research design has employed to collect the relevant information for the study.

\section{RESEARCH METHODOLOGY}

\subsection{Description of the Study Area}

Yabello woreda is one of the thirteen (13) woredas of Borena zone located at $567 \mathrm{~km}$ to the south of Addis Ababa along the main Addis Ababa - Nairobi international road. According to the Central Statistics Agency (CSA, 2007) the total land cover of the woreda is $5523 \mathrm{~km}^{2}$ from which $60 \%$ is pasture land.

Yabello woreda has semiarid climatic condition characterized by erratic and low annual rainfall. Annual rainfall ranges between 350 to $900 \mathrm{~mm}$ in the woreda, with $21 \%$ to $68 \%$ coefficient of variability (YWFSO, 2016). 
According to the 2007 population censes (CSA, 2007) the total population of Yabello woreda was 102,165 out of which 51,418 were males and 50,747 females, rural population represented $(82.87 \%)$ of the total. It has a total of 18,183 households with nearly average household size of 5.4 .

\subsection{Study Design}

Based on the research objectives, research questions and the existing reality in the study area cross-sectional was considered appropriate for the study, because cross-sectional or social survey design helps to examine varieties of social phenomenon at a single point of time from a sample drawn from a specified population. The study was used both quantitative and qualitative data to achieve its objectives.

\subsection{Data Types and Data Sources}

Both quantitative and qualitative data from primary and secondary data sources were used. As Participatory Rural Appraisal (PRA) tools allowed the local people to participate actively in identification of problems, those tools were used to generate qualitative data from primary data sources on the knowledge and experience of the local people concerning food security situations. Secondary data was collected from records and official statistics from Borena zone disaster prevention and preparedness office, Yabello woreda administration office, food security office and disaster prevention and preparedness office.

\subsection{Methods of Data Collection}

Interview Schedule:-Primary data was collected from sampled respondents by using semi-structured interview schedule. Three enumerators with full knowledge of the localities, culture and language of the people were recruited and trained on the objectives of the study and how to conduct data collection.

Focus Group Discussions:- Checklists were prepared and used for Focus group discussions (FGDs). Two FGDs, one involving male and the other female headed households, were conducted in each of the three kebeles. The participants of Focus group discussions were ordinary agro- pastoralists which are not included in individual interviews.

Key Informants Interview: - are people who have special knowledge and experience about the study area and objectives of the study. Using relevant checklists experts specifically development agents working in these kebeles, elders and administrators of the kebeles and officials of woreda administration used by the people.

\subsection{Sampling Methods and Procedures}

Purposive sampling technique was used to select Yabello Woreda from the thirteen (13) woredas of Borena zone. Similarly the study kebeles Obda, Yubdo and Ganya were purposively selected from the twenty three (23) kebeles of the woreda mainly because the livelihood of the people living in these kebeles is totally dependent up on agro pastoralism compared to the rest of the kebeles.

Finally simple random sampling was used to select sample households from the three kebeles. By using the kebele record lists as a sampling frame, a total of 168 household heads were randomly selected from the three kebeles based on the probability proportional to size approach. With the total 4,756, a simplified formula provided by Yemane (1967) was used to calculate the sample size:-

Where: $-\mathrm{n}$ is the sample size.

$$
n=\frac{\mathrm{N}}{1+N(\mathrm{e})^{2}}
$$

$\mathrm{N}$ is the total population.

e is the expected level of precision.

Thus the sample size was (with $93 \%$ confidence or 0.07 precision levels) $n=\frac{937}{1+937(0.07)^{2}}=168$

Table1Sample kebeles number of households and respective sample size

\begin{tabular}{lcc}
\hline Sample kebeles & $\begin{array}{c}\text { Number of } \\
\text { households }(\mathrm{N})\end{array}$ & $\begin{array}{c}\text { Number of sample } \\
\text { household heads (n) }\end{array}$ \\
\hline Obda & 256 & $168 * 256 / 937=46$ \\
Yubdo & 514 & $168 * 514 / 937=92$ \\
Ganya & 167 & $168 * 167 / 937=30$ \\
Total & 937 & $46+92+30=168$ \\
\hline
\end{tabular}

\subsection{Methods of Data Analysis}

In this study different descriptive statistics, independent sample t- test, chi- squire test and binary logistic regression in (SPSS) statistical package for social science version 21 were employed to analyze data from different sources. 


\section{RESULTS AND DISCUSSION}

\subsection{Household Demographic and Socio-Economic Characteristics}

In this section the demographic and socio-economic characteristics of the households such as size of the household, age of the household heads, sex of the household heads, dependency ratio and household heads level of education were given due attention. The variables discussed here may have significant relationship with household's status of food security in the study area.

\subsubsection{Household Size}

The number of household is most commonly used variable in food security related studies to see how household size affects the status of food security. In the same manner this study also examined if there is association between household size and status of food security. As shown in Table 3 that the maximum household size in adult age was 8.05 from food secured respondents no households have fall in the highest range $(5.91-8.05)$. On the other hand $60.4 \%$ of food insecure respondent fall in the highest household size range in addition $34.3 \%$ of food secured respondent fall in the lowest range $(0.75-2.95)$ and $27 \%$ from food insecure groups. This shows that the higher the household size measured in adult age the lower the status of household food security and more it is related to food insecurity in the area. The mean household size for food secured and food insecure respondents was 4.08 and 6.27 respectively with the standard deviation 1.362 and 1.224 while that of the total sample was 5.404.

Thus the distribution of sample households with regard to household size measured in adult age shows a statistical difference between food secured and food insecure groups.

Table2 Sampled households' distribution by size

\begin{tabular}{|c|c|c|c|c|c|c|}
\hline \multirow[t]{2}{*}{$\begin{array}{l}\text { Households size in Adult } \\
\text { age }\end{array}$} & \multicolumn{2}{|c|}{$\begin{array}{l}\text { Food secured respondents } \\
(n=67)\end{array}$} & \multicolumn{2}{|c|}{$\begin{array}{l}\text { Food insecure } \\
\text { respondents }(n=101)\end{array}$} & \multicolumn{2}{|c|}{$\begin{array}{l}\text { Total respondents } \\
(\mathrm{N}=168)\end{array}$} \\
\hline & Frequency & $\%$ & Frequency & $\%$ & Frequency & $\%$ \\
\hline $0.75-2.95$ & 23 & 34.34 & 6 & 5.9 & 27 & 16.1 \\
\hline $2.96-4.99$ & 26 & 38.8 & 5 & 5.0 & 33 & 19.6 \\
\hline $5.00-5.90$ & 18 & 26.9 & 29 & 28.7 & 47 & 28.0 \\
\hline $5.91-8.05$ & 0 & 0 & 61 & 60.4 & 61 & 36.3 \\
\hline Maximum & \multicolumn{2}{|c|}{5.90} & \multicolumn{2}{|c|}{8.05} & \multicolumn{2}{|c|}{8.05} \\
\hline Minimum & \multicolumn{2}{|c|}{1.75} & \multicolumn{2}{|c|}{2.95} & \multicolumn{2}{|c|}{1.75} \\
\hline Mean & \multicolumn{2}{|c|}{4.08} & \multicolumn{2}{|c|}{6.27} & \multicolumn{2}{|c|}{5.404} \\
\hline St. Deviation & \multirow{2}{*}{\multicolumn{2}{|c|}{1.362}} & \multicolumn{2}{|c|}{1.224} & \multirow{2}{*}{\multicolumn{2}{|c|}{1.680}} \\
\hline t-test value & & & \multicolumn{2}{|c|}{10.767} & & \\
\hline
\end{tabular}

Source survey result (2017)

\subsubsection{Age of the Household Heads}

Age is a continuous explanatory variable peculiar to the household heads. In this study it was used to measure the age of the household head in years. In rural areas most household heads devote their time on farming or animal husbandry activities. The distribution of age groups of the sampled respondents is shown in Table4 bellow. The average age of the total sampled respondents was (45). Likewise the maximum and minimum age was 67 and 22 years respectively. The t- value 4.73 and $\mathrm{P}$ Value $<0.05$ shows statistically significant difference in the age of respondents between the two groups.

Table3Distribution of age groups for the sampled respondents

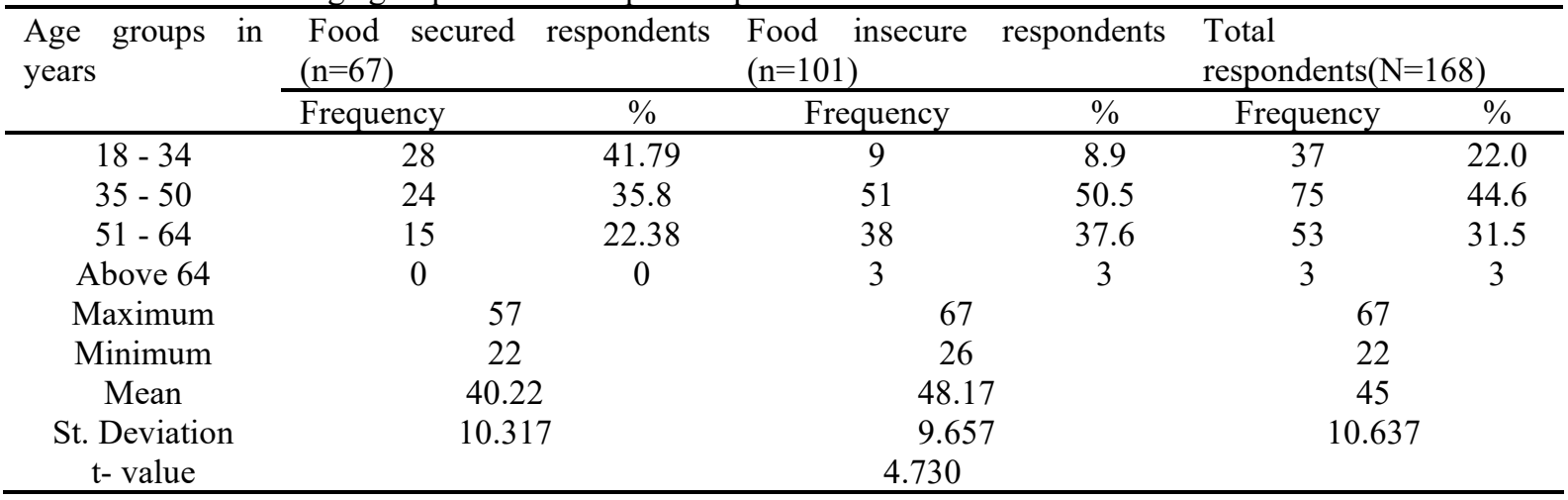

Source survey result (2017)

\subsubsection{Sex of the Household Heads}

From the total 168 respondents of the survey $89.3 \%$ household heads were male household heads and $10.7 \%$ are female heads. It is found that 3.0\% from food secured and $15.8 \%$ from food insecure households are female heads. It is important to note that $97 \%$ from food secured and $84.2 \%$ from food insecure were male heads as shown in Table5 bellow. 
Table4 Distribution of sampled respondents by sex

\begin{tabular}{lcccccc}
\hline Sex of respondents & $\begin{array}{l}\text { Food secured respondents } \\
(\mathrm{n}=67)\end{array}$ & $\begin{array}{l}\text { Food insecure } \\
(\mathrm{n}=101)\end{array}$ & respondents & \multicolumn{2}{l}{$\begin{array}{l}\text { Total respondents } \\
(\mathrm{N}=168)\end{array}$} \\
\cline { 2 - 7 } & Frequency & $\%$ & Frequency & $\%$ & Frequency & $\%$ \\
\hline Male heads & 65 & 97 & 85 & 84.2 & 150 & 89.3 \\
Female heads & 2 & 3.0 & 16 & 15.8 & 18 & 10.7 \\
Chi-Square value & & & 6.960 & & & \\
\hline
\end{tabular}

Source survey result (2017)

\subsubsection{Dependency Ratio}

Dependency ratio was expected to have negative relationship with household food security in that household with less dependency ratio is more food secure than household with large dependency ratio. The mean dependency ratio for the total sampled households was 1.6 (SD 1.31) with the maximum of 4.0 and minimum of no dependency. The mean dependency ratio was 0.56 (SD 0.75) and 2.36 (SD 1.08) for food secure and food insecure groups respectively. So that there was statistically significant mean difference of dependency ratio between the two groups at less than $1 \%$ probability level therefore the study shows that food insecure household had high dependency burden than food secured households which may increase vulnerability of household to food shortage.

\subsubsection{Educational level of the Sampled Household Heads}

The educational status of the household heads is an important human capital which is expected to affect status of household food security. The overall educational status of the sampled respondents is presented in Table6 bellow

\begin{tabular}{|c|c|c|c|c|c|c|}
\hline \multirow[t]{2}{*}{ Educational status of respondents } & \multicolumn{2}{|c|}{$\begin{array}{l}\text { Food secured respondents } \\
(\mathrm{n}=67)\end{array}$} & \multicolumn{2}{|c|}{$\begin{array}{l}\text { Food insecure } \\
\text { respondents } \\
(\mathrm{n}=101)\end{array}$} & \multicolumn{2}{|c|}{$\begin{array}{l}\text { Total } \\
\text { respondents }(\mathrm{N}=168)\end{array}$} \\
\hline & Frequency & $\%$ & Frequency & $\%$ & Frequency & $\%$ \\
\hline $\begin{array}{lll}\text { Illiterate } & \text { (without } & \text { Formal } \\
\text { Education) } & & \\
\end{array}$ & 27 & 40.29 & 82 & 81.2 & 109 & 64.9 \\
\hline Literate (With Adult Education) & 28 & 41.79 & 13 & 12.9 & 41 & 24.40 \\
\hline $\begin{array}{l}\text { Literate (With Formal Education } \\
\text { Grade1-10) }\end{array}$ & 12 & 17.910 & 6 & 5.9 & 18 & 10.71 \\
\hline $\begin{array}{l}\text { Above Grade } 10 \\
\text { Chi square Value }\end{array}$ & 0 & 0 & $\begin{array}{c}0 \\
29.556\end{array}$ & 0 & 0 & 0 \\
\hline
\end{tabular}

Table 6 Overall educational status of sampled respondents

Source survey result (2017)

As it is showed in the above Table 6 the survey result indicate that out of the total sampled respondent around $64.9 \%$ of them didn't attend any form of education be it formal or informal education. The rest $35.11 \%$ have attended both formal and informal education where $10.7 \%$ have attended formal education and $24.4 \%$ attended informal (Adult education). It was found that out of the total illiterate household heads $40.29 \%$ were food secured and the rest $81.2 \%$ were food insecure. Whereas from the total literate household heads $59.7 \%$ were food secured and $18.8 \%$ were food insecure. Therefore the chi-square value 29.55 shows statistically significant difference at $P$ is $<0.05$ among the two groups.

\subsection{Economic Characteristics of the Sampled Household Heads}

The economic characteristics of households is discussed in this section and seen how it relates to food secured and insecure groups. Economic aspects of households include size of cultivated land, number of livestock owned, number of oxen owned, and off /non farm income were given due attention.

\subsubsection{Size of Cultivated Land by the Sampled Household Heads}

As shown in Table7 bellow on average each respondent household heads posses 1.653ha of land. The maximum cultivated land holding was $6.50 \mathrm{ha}$ for the total sampled respondents. All respondents have access to agricultural land. From food secured groups about $64.17 \%$ posses cultivated land holding that ranges between $2.6-6.5 \mathrm{ha}$ while $76.237 \%$ of food insecure respondents possessed $0.1-2.5 \mathrm{ha}$. As shown in the Table 7 there is significant mean difference between the two groups 3.084 and 0.762 for food secured and food insecure respondents respectively. The $\mathrm{t}$ - value -16.5 and $\mathrm{P}$ Value $<0.05$ shows that size of cultivated land holding has significant effect on status of household food. This result is similar to the findings Mequanint (2009). 
Table7Cultivated land size of sampled respondents

\begin{tabular}{|c|c|c|c|c|c|c|}
\hline \multirow[t]{2}{*}{$\begin{array}{l}\text { Size of cultivated } \\
\text { Land in Hectare }\end{array}$} & \multicolumn{2}{|c|}{$\begin{array}{l}\text { Food secured respondents } \\
(\mathrm{n}=67)\end{array}$} & \multicolumn{2}{|c|}{$\begin{array}{l}\text { Food insecure respondents } \\
(\mathrm{n}=101)\end{array}$} & \multicolumn{2}{|c|}{ Total respondents $(\mathrm{N}=168)$} \\
\hline & Frequency & $\%$ & Frequency & $\%$ & Frequency & $\%$ \\
\hline 0 & 0 & 0 & 24 & 23.762 & 24 & 14.285 \\
\hline $0.1-2.5$ & 21 & 31.343 & 77 & 76.237 & 98 & 58.333 \\
\hline $2.6-4.5$ & 37 & 55.223 & 0 & 0 & 37 & 55.223 \\
\hline $4.6-6.5$ & 9 & 13.432 & 0 & 0 & 9 & 5.357 \\
\hline Above 6.5 & 0 & 0 & 0 & 0 & 0 & 0 \\
\hline Maximum & \multicolumn{2}{|c|}{6.50} & \multicolumn{2}{|c|}{2.50} & \multicolumn{2}{|c|}{6.50} \\
\hline Minimum & \multicolumn{2}{|c|}{0.5} & \multicolumn{2}{|c|}{00} & \multicolumn{2}{|c|}{00} \\
\hline Mean & \multirow{2}{*}{\multicolumn{2}{|c|}{$\begin{array}{l}3.084 \\
1.263\end{array}$}} & \multirow{2}{*}{\multicolumn{2}{|c|}{$\begin{array}{l}0.762 \\
0.568\end{array}$}} & \multicolumn{2}{|c|}{1.653} \\
\hline St. Deviation & & & & & & \\
\hline $\mathrm{t}$ - test value & & & \multicolumn{2}{|c|}{-16.51} & & \\
\hline
\end{tabular}

Source survey result (2017)

\subsubsection{Number of Livestock Owned by the Sampled Household Heads}

Livestock are the most important source of livelihood in Borena pastoral and agro pastoral households. Households who have large numbers of livestock have more probability of being food secured than the one who have few numbers of livestock. Hence the higher the value of TLU the higher the probability of being food secured. Adunya and Wogayehu (2011) in their study conducted in Welayta found that households with more number of livestock have more probability to be food secured than households with less number of livestock. This study found that the maximum and minimum livestock holding was 25.14 and 1.00 TLU with mean of 8.197 TLU (SD 5.142). The mean TLU for food secured and food insecure households was 12.881 TLU (SD 4.774) and 5.086 TLU (SD 2.139) respectively. The t- test value 14.394 and $\mathrm{P}$ value $<0.05$ indicates that there is statistically significant difference between the means of the two groups.

Table8Average distribution of livestock ownership among sampled respondents in TLU

\begin{tabular}{ccccc}
\hline Livestock holding in TLU & $\begin{array}{l}\text { Food } \\
\text { respondents }(\mathrm{n}=67)\end{array}$ & $\begin{array}{l}\text { secured } \\
\text { respondents }(\mathrm{n}=101)\end{array}$ & $\begin{array}{l}\text { Total } \\
\text { respondents }(\mathrm{N}=168)\end{array}$ \\
\hline Maximum & 25.14 & 9.81 & 25.14 \\
Minimum & 3.66 & 1.00 & 1.00 \\
Mean & 12.881 & 5.086 & 8.197 \\
St. Deviation & 4.774 & 2.139 & 5.142 \\
t- test value & & -14.021 & \\
\hline
\end{tabular}

Significant at less than one percent (1\%) probability level

Source survey result 2017

\subsubsection{Number of Oxen Owned by the Sampled Household Heads}

Oxen are the most important resources that serve as traction power in the study area. In this study it was hypothesized that the number of oxen owned by the households is positively related with household status of food security. That is the more the number of oxen the more the probability of the households being food secured. The mean value of oxen owned by sampled households was 0.76 (SD 1.135). The mean value of oxen ownership by food secured and food insecure groups was 1.52 (SD 1.352) and 0.25 (SD 0.537) respectively. The mean oxen ownership by food secured respondents was greater compared to the food insecure groups. The t-test value -8.525 shows a statistically significant mean difference at less than one percent probability level as shown in the Table9 bellow. 
Table9 Distribution of oxen ownership among the sampled respondents

\begin{tabular}{|c|c|c|c|c|c|c|}
\hline \multirow[t]{2}{*}{$\begin{array}{l}\text { Number of oxen } \\
\text { owned by respondents }\end{array}$} & \multicolumn{2}{|c|}{$\begin{array}{l}\text { Food secured } \\
\text { respondents }(\mathrm{n}=67)\end{array}$} & \multicolumn{2}{|c|}{$\begin{array}{l}\text { Food insecure respondents } \\
(\mathrm{n}=101)\end{array}$} & \multicolumn{2}{|c|}{ Total respondents $(\mathrm{N}=168)$} \\
\hline & Frequency & $\%$ & Frequency & $\%$ & Frequency & $\%$ \\
\hline 0 & 18 & 26.86 & 81 & 80.2 & 104 & 61.90 \\
\hline 1 & 16 & 23.88 & 15 & 14.9 & 37 & 22.02 \\
\hline 2 & 24 & 35.82 & 5 & 5.0 & 18 & 10.71 \\
\hline 3 & 0 & 0 & 0 & 0 & 3 & 1.78 \\
\hline 4 & 8 & 11.9 & 0 & 0 & 5 & 2.97 \\
\hline 5 & 0 & 0 & 0 & 0 & 0 & 0 \\
\hline 6 & 1 & 1.5 & 0 & 0 & 1 & 0.59 \\
\hline Maximum & \multicolumn{2}{|c|}{6} & \multicolumn{2}{|c|}{2} & \multicolumn{2}{|c|}{6} \\
\hline Minimum & \multicolumn{2}{|c|}{0} & \multicolumn{2}{|c|}{0} & \multicolumn{2}{|c|}{0} \\
\hline Mean & \multirow{2}{*}{\multicolumn{2}{|c|}{$\begin{array}{l}1.52 \\
1.352\end{array}$}} & \multirow{2}{*}{\multicolumn{2}{|c|}{$\begin{array}{c}0.25 \\
0.537\end{array}$}} & \multicolumn{2}{|c|}{0.76} \\
\hline St. Deviation & & & & & & \\
\hline $\mathrm{t}$ - test value & & & \multicolumn{2}{|c|}{4.86} & & \\
\hline
\end{tabular}

Significant at less than one percent (1\%) probability level

Source survey result 2017

\subsubsection{Off/Non- Farm Income of the Households}

Off/non- Farm income generating activities have significant contribution in meeting household consumption as well as purchase of agricultural inputs. This study found that the maximum off/non- farm income earned was ETB 3700 and the minimum 460 with mean value of 1370.98 (SD 939.623) per year during the survey time. The food secured groups earned maximum of ETB 3700 and minimum of 620 with mean value 2206.70 (SD 855.76). At the same time the food insecure groups earned maximum of ETB 2200 and minimum 460 with mean value 798.425 (SD 401.20) per year. Therefore the mean difference among the two groups shows that there was significant relation with off/non- farm and status of household food security. t- Value (-14) signifies that there is significant mean difference between the two groups at less than one percent probability level as shown in the Table10 bellow Table10Off/None-farm income distribution among sampled respondents

\begin{tabular}{ccccc}
\hline $\begin{array}{l}\text { Annual } \\
\text { income }\end{array}$ & $\begin{array}{l}\text { Food } / \text { Non- } \\
\text { respondents }(\mathrm{n}=67)\end{array}$ & $\begin{array}{l}\text { Food } \\
\text { respondents }(\mathrm{n}=101)\end{array}$ & $\begin{array}{l}\text { insecure } \\
\text { respondents }(\mathrm{N}=168)\end{array}$ \\
\hline Maximum & 3700 & 2200 & 3750 \\
Minimum & 620 & 460 & 460 \\
Mean & 2206.70 & 798.425 & 1370.98 \\
St. Deviation & 855.76 & 401.20 & 939.623 \\
t- test value & & -14.219 & \\
\hline
\end{tabular}

Significant at less than one percent (1\%) probability level

Source survey result 2017

\subsection{Institutional Factors}

Institutional factor that may have significant relationship with household food security are discussed in this section. The variables discussed include use of chemical fertilizers, access to credit service and distance to the market.

\subsubsection{Use of Chemical Fertilizers}

Appropriate use of modern farm inputs like chemical fertilizers, improved seeds, improved animal breeds can increase yield and productivity of the households and bring them to become food secured. From this fact farmers have been encouraged to adopt utilization of modern farm inputs to improve land productivity and to boost overall production (Degefa, 2002). Majority of both foods secured and food insecure respondents are users of farm inputs especially improved seeds. On the other hand the majority of respondents in both groups didn't used chemical fertilizers for different reasons. From the total sampled respondents $129(76.8 \%)$ of them didn't use chemical fertilizers for their farming activities while $39(23.2 \%)$ of them used chemical fertilizers in their farm. The proportion of chemical fertilizer users was $35.8 \%$ and $14.9 \%$ for food secured and food insecure groups respectively. Whereas the proportion of non users accounted for $64.2 \%$ and $85.1 \%$ for food secured and food insecure groups respectively. Hence the $\mathrm{X}^{2}$ - value 9.366 and $\mathrm{P}$ Value $<0.05$ shows there is statistically significant proportion difference among the two groups in using chemical fertilizer in their farming activities as shown in Table11 bellow 
Table11Distribution of users and non- users of chemical fertilizers among respondents

\begin{tabular}{|c|c|c|c|c|c|c|}
\hline \multirow[t]{2}{*}{$\begin{array}{l}\text { Use of } \\
\text { fertilizers }\end{array}$} & \multicolumn{2}{|c|}{$\begin{array}{l}\text { Food secured } \\
\text { respondents }(n=67)\end{array}$} & \multicolumn{2}{|c|}{$\begin{array}{l}\text { Food insecure respondents } \\
(\mathrm{n}=101)\end{array}$} & \multicolumn{2}{|c|}{$\begin{array}{l}\text { Total } \\
\text { respondents }(\mathrm{N}=168)\end{array}$} \\
\hline & Frequency & $\%$ & Frequency & $\%$ & Frequency & $\%$ \\
\hline Users & 24 & 35.8 & 15 & 14.9 & 39 & 23.2 \\
\hline Non - Users & 43 & 64.2 & 86 & 85.1 & 129 & 76.8 \\
\hline Chi - Square value & \multicolumn{6}{|c|}{9.936} \\
\hline
\end{tabular}

Significant at less than five percent (5\%) probability level

Source survey result 2017

\subsubsection{Access to Credit Service by the Households}

OSCSC (Oromia saving and credit share company) is the major institute which provides saving and credit service in the study area. Credit service increases the probability of the households to become more secure in different situations including food security. From the total sampled respondents $39.3 \%$ of them have got access to credit service and the rest $60.7 \%$ didn't have access to credit service. From the total credit accessed respondents $3958.2 \%$ from food secured and $26.7 \%$ from food insecure groups. On the other hand the proportion of respondents which did not access credit service was $41.7 \%$ and $73.2 \%$ for food secured and food insecure groups respectively. The Chi- square test value 16.731 shows statistically significant proportion difference at less than $1 \%$ level of probability as shown in the Table12 bellow

Table12Access to credit by sampled respondents

\begin{tabular}{|c|c|c|c|c|c|c|}
\hline \multirow[t]{2}{*}{$\begin{array}{l}\text { Access to } \\
\text { service }\end{array}$} & $\begin{array}{l}\text { Food secured } \\
(n=67)\end{array}$ & respondents & $\begin{array}{l}\text { Food } \\
\text { respondent }\end{array}$ & $\begin{array}{l}\text { insecure } \\
01)\end{array}$ & \multicolumn{2}{|c|}{ Total respondents $(\mathrm{N}=168)$} \\
\hline & Frequency & $\%$ & Frequency & $\%$ & Frequency & $\%$ \\
\hline Accessed & 39 & 58.208 & 27 & 26.732 & 66 & 39.3 \\
\hline Non accessed & 28 & 41.791 & 74 & 73.267 & 102 & 60.71 \\
\hline Chi- square value & \multicolumn{6}{|c|}{16.731} \\
\hline
\end{tabular}

Significant at less than one percent (1\%) probability level

Source survey result 2017

\subsubsection{Distance walked to the Market by the Sampled Household}

Better infrastructure is essential for food security by insuring low food price and efficient market that can respond to change in demand. It also reduces the cost of transporting produce and inputs and food shortage. It allows information transfer between producers and traders and gives farmers access to new technologies (FAO, 2010). The maximum and minimum distance traveled by the total sampled respondents to the nearby market was 3 to $13 \mathrm{~km}$ with mean distance of $6.4 \mathrm{kms}$. The mean distance traveled by food secured respondents was 4.3 with maximum and minimum distance of 3 to $8 \mathrm{~km}$. whereas the mean distance traveled by food insecure groups was $6.3 \mathrm{~km}$ with maximum and minimum distance of 3 to $13 \mathrm{~km}$. So that there is statistically significant difference between the two groups as indicated by t- test value of 9.979

Table13Distribution of average distance walked by the sampled respondents

\begin{tabular}{ccccc}
\hline The average Distance Walked & $\begin{array}{l}\text { Food } \\
\text { respondents }(\mathrm{n}=67)\end{array}$ & $\begin{array}{l}\text { secured } \\
\text { Food } \\
\text { respondents }(\mathrm{n}=101)\end{array}$ & $\begin{array}{l}\text { Total } \\
\text { respondents }(\mathrm{N}=168)\end{array}$ \\
\hline Maximum & 8 & 13 & 13 \\
Minimum & 3 & 3 & 3 \\
Mean & 4.33 & 7.722 & 6.366 \\
SD & 1.204 & 2.397 & 2.608 \\
t- value & & 9.979 & \\
\hline
\end{tabular}

Significant at less than (1\%) probability level

Source survey result 2017

\subsection{Parameter Estimates of Binary Logistic Regression}

Binary logistic regression model was used to identify the factors that affect household food security in the study area. 
Table15 Logistic regression model output

\begin{tabular}{lccccc}
\hline Variables & Coefficient & SE & Wald & p-value & Odd ratio \\
\hline Sex of the Household heads (SEXHHHS) & 0.902 & 3.16 & 0.081 & 0.776 & 2.463 \\
Age of the Household heads (AGEHHHS) & -0.054 & 0.085 & 0.405 & 0.525 & 0.948 \\
Educational level of Household heads (EDULHHH) & 0.129 & 1.229 & 0.011 & 0.916 & 1.138 \\
Household size (HHSIZAE) & -0.943 & 0.445 & 4.485 & $0.034^{*}$ & 0.389 \\
Dependence ratio (DRATIO) & -0.858 & 0.616 & 1.935 & 0.164 & 0.424 \\
Livestock ownership (NLSTOCK) & 0.405 & 0.161 & 6.358 & $0.012^{*}$ & 1.499 \\
Oxen ownership (NOXEN) & 0.540 & 0.641 & 0.711 & 0.399 & 1.716 \\
Size of cultivated land (SCLAND) & 1.471 & 0.556 & 6.997 & $0.008^{*}$ & 4.352 \\
Off farm income (OFINCOM) & 0.01 & 0.01 & 0.546 & 0.460 & 1.001 \\
Access to credit service (ACCREDIT) & 0.741 & 0.442 & 2.815 & 0.093 & 2.099 \\
Use of chemical fertilizers (UCFERTI) & 1.381 & 0.525 & 6.907 & $0.009 *$ & 3.977 \\
Distance to the market (DMARKET) & -1.037 & 0.176 & 34.568 & $0.000^{*}$ & 0.355 \\
\hline
\end{tabular}

Level of significance, $\mathrm{p}<0.05$

Source survey result (2017)

In the study the variables which are expected to have influence on household food security were tested in the model. The model output shows that from the total twelve (12) variables five (5) of them were found to be significant. Among the variables fitted in to the model; household size, livestock ownership, size of cultivated land, use of chemical fertilizers and distance to the market are found to be significant at less than one (1\%) and five (5\%) percent probability level. Household size result was coincides with findings of Ayalew (2003), Tesfaye (2005), Guled (2006) and Mequanint (2009). Similarly, the livestock ownerships result was coincides with findings of Mulugeta (2002), Sadiq (2012) and Abdurrahman (2015). Results regarding to size of cultivated land was correlated with the findings of Guled (2006), Mequanint (2009). Results related to the use of chemical fertilizers was coincides with the findings of Mequanint (2009) and also results related to distance to market was coincides with the findings of Lewin and Fisher, (2010) and Abdurrahman, (2015).

\subsection{Conclusion and recommendation}

Food security is one of the critical issues that need to be addressed in Ethiopia. Both government and nongovernmental organizations played a key role to reduce food security problems in the country. As part of this effort, the government of Ethiopia has implemented different food security programs. Yabello woreda was also incorporated in these programs. However situations indicate that the problem of food security still requires additional intervention to solve the problem in sustainable manner. Therefore this study was conducted in Yabello woreda of Borena zone, Oromia Region with the specific objectives of factors affecting household food security and socio economic characteristics of the respondents in the Agro pastoral kebeles. In order to achieve the stated objectives after primary and secondary data collection, focus group discussions and key informants The data were analyzed using SPSS (version 21) software employing descriptive statistics. The total sampled households were classified as food secured and food insecure households by using household calorie acquisition method .Accordingly $39.9 \%$ were food secure $61.1 \%$ food insecure. The explanatory variables were household size, sex of the household head, age of the household head, educational level of the household head, dependency ratio, number of livestock owned, number of oxen owned, size of cultivated land, off/none farm income, access to credit service, use of chemical fertilizers and distance walked to the market. The fallowing interventions are recommended based on results of findings.

$>$ Household size was found to be significant and negatively related with household status of food security. Therefore proper attention should be given to limit the rate of population growth in the study area.

$>$ The livestock ownership in TLU was found to be significant and positively related with household status of food security. Therefore concerned governmental and non-governmental bodies in this area are suggested to establish additional ranches to protect the pure Borena breed which is known in its milk and meat production and distribute

$>$ Size of cultivated land was found to be significant and positively related with household status of food security. Therefore concerned bodies who are working in this area are suggested to encourage the society to cultivate and produce more diversified crops by providing training, supporting the households with improved seed (drought tolerant seed varieties), supplementing the household activities with different agricultural technologies and expanding additional agricultural extension services.

$>$ Use of chemical fertilizers was found to be significant and positively related with household status of food security. Therefore this study suggests that governmental and other concerned bodies should encourage households to use chemical as well as organic fertilizers in their farming activities, supplement appropriate type of fertilizer timely with affordable price, improve their income through additional microfinance services, provide expanded training service, technical support and expanded agricultural extension services in the future. 
$>$ Distance to the market was found to be significant and negatively related with household status of food security. Therefore concerned governmental and other bodies should have to establish additional market centers near the villages and they are suggested to construct expanded rural roads that may facilitate the transport service in the study area.

$>$ Further study with additional predictor variables have to be made so as to address the issues raised in this study.

\section{REFERENCES}

Abdurahman Ahmed (2015). Food insecurity and coping strategies of Agro -pastoral households in Babile district of Somali regional state: MSc. Thesis, Haramaya University, Haramaya, Ethiopia.

Abiyot Tilahun (2008). Challenges of livelihood diversification and coping strategies among the pastoralist in Debub Omo zone: The case of Hammer woreda MA. Thesis, Addis Ababa University, Ethiopia

Adunya Eniyew and Wogayehu Bekele (2011). Causes of household food insecurity in Wolayita southern Ethiopia: Journal of stored products and post harvest research.

BirukYemane (2003). Food insecurity in pastoral areas of Ethiopia

CAADP (2009). Policy framework for food security in pastoralist area cumulative draft

CSA (2007). Population censes, Addis Ababa, Ethiopia.

ECSA (2011), Central Statistics Agency population censes estimate, Addis Ababa, Ethiopia.

Chung, K., L. Haddad, J. Ramakrishna and F. Riely (1997). Identifying the food insecure: The application of mixed method approach in India

Di. Falco, S., Varonsi, M. and M. Yosef(2011). Does adaptation to climate change provide food security? A micro perspective from Ethiopia, American journal of agricultural economics

DagafaTolossa (2003). Household seasonal food insecurity in Oromia region, Ethiopia: Cases organization for social science research in eastern and southern Africa. Research report number 26 Addis Ababa Ethiopia.

Diminguez, A. (2010). Why was still malnutrition in Ethiopia? Causes and humanitarian accountability Journal of humanitarian affairs http://sites.tufts.edu/jaha/archive/640

FassilKibebew (2001). Traditional coping strategies in the Afar and Borena pastoralists in response to drought DCG report number 17.

FAO (2013). Crop and food security assessment mission to Ethiopia, www.fao.org

GetachewDiriba (1995). Economy at cross roads, famine and food security in rural Ethiopia, Addis Ababa, Ethiopia

Guledabdulahi (2006).Food insecurity and coping strategies in agro pastoral households in Awbareworeda. MSc. Thesis, Haramaya University, Haramaya, Ethiopia

Habtom, K., Z. Gudata and G. Gundhalande (2005). Causes of household food insecurity in Koredagaga peasant association Oromia region Ethiopia, African journal of agriculture and food security

MequanintMuche (2009). Determinants of household food security and coping strategies: The case of Adabergaworeda, west Shoa zone, Ethiopia. MSc. Thesis Haramaya University, Haramaya, Ethiopia

MoFED (2008). Sustainable development and poverty reduction program MoFED Addis Ababa, Ethiopia.

Mulugeta Tefera (2002). Determinants of household food security in eastern Oromia, Ethiopia: The case

SadiqAbdi (2012). Dimensions and determinants of food insecurity among agro pastoral households in Jigjiga district, Somali regional state, Ethiopia. MSc. Thesis Haramayauniversity, Haramaya, Ethiopia.

Osei Mensah etal (2013). Determinants of Household Food Security in the Sekyere-Afram Plains District of Ghana 